\title{
The Spirituality of St. Antony of Egypt: Lessons for Contemporary African Pentecostalism
}

\section{Joshua D. Settles ${ }^{1}$ (iD}

1 Akrofi-Christaller Institute of Theology, Mission, and Culture, Akropong-Akuapem, Ghana.

\begin{abstract}
This study is an examination of the spirituality of St Antony of Egypt. It examines the historical, intellectual, and religious context of St Antony's life and ministry, including his worldview and how these inform his spirituality. The study is a literary study and utilizes existing primary and secondary source materials on Antony's life, including his seven extant letters which are assessed as to their credibility. The study explores St Antony's understanding and use of scripture, prayer, and spiritual warfare. From these, the study draws lessons relevant for contemporary African Pentecostalism.
\end{abstract}

Correspondence: Joshua D. Settles Email: jdsettles@aci.edu.gh

Publication History Received 11th November 2021, Accepted 7th December 2021, Published online 17th December 2021.

Keywords: Spirituality, St. Antony of Egypt, African Pentecostalism

\section{INTRODUCTION}

'Understanding is the reward of faith. Therefore, do not seek to understand in order to believe, but believe that thou mayest understand. ${ }^{1}$ This idea, first advanced by the great African theologian, St. Augustine and later taken up and expanded upon by St. Anselm may be considered foundational to Christian theology. It is the self-disclosure of God that enables the possibility of faith, and it is a reflection upon this faith that results in theology. Nevertheless, all too often within the academy, theology has been conceptually restricted to 'systematic theology', 'formal presentation', and 'propositional articulation'. ${ }^{2}$ This restriction leads invariably to a divorce of spirituality from theology. Thus, for many African Pentecostals for whom 'the experience of the Spirit, empowerment, dynamism in worship and a spirituality that is felt within everyday endeavours' ${ }^{3}$ are key characteristics of Christian faith, theology is sometimes viewed with suspicion. Yet the African theologian Kwesi Dickson helpfully provides a reminder: 'for the Christian theologian the ultimate reality is Christ', ${ }^{4}$ and reflection upon the reality of Christ 'may not issue in the expression of one's thinking in coherent language. The reflection may be done in song, or in prayer, in action or in mediation.' ${ }^{5}$ In other words, theology is effectively a means by which one seeks to articulate what Rudolph Otto calls the numinous,

1 St. Augustine, Homilies on the Gospel of John; Homilies on the First Epistle of John; Soliloquies: Tractate 29, in Philip Schaff (ed.) Nicene and Post-Nicene Fathers of the Christian Church Vol. 7 (Edinburgh: T\&T Clark, Second Printing 1995), 183 186 (184).

2 Kwesi Dickson, African Theology (London: Darton, Longman \& Todd Ltd., 1984), 5.

3 Johnson Kwabena Asamoah-Gyadu, Sighs and Signs of the Spirit: Ghanaian Perspectives on Pentecostalism and Renewal in Africa (Akropong-Akuapem: Regnum Africa, 2015), 5.

4 Dickson, African Theology, 38.

5 Dickson, African Theology, 13-14. 
that which 'finds its most unqualified expression in the spell exercised by the only half intelligible or wholly unintelligible language of devotion, and in the unquestionably real enhancement of the awe of the worshipper which this produces. ${ }^{6}$ Theology is primarily a spiritual quest, especially when there is an understanding of Christian spirituality not just as any subjective human response to the numinous, but as a faithful answer to the 'Christian story revolving around the life, death and resurrection of Jesus of Nazareth'. ${ }^{7}$ Put differently, Christian theology and spirituality are inseparable. Therefore, it is important for the theological reflection of African Pentecostals to be shaped by a lively spirituality and dynamic engagement with the Spirit of God. This will enable their work to become transformative for themselves and others.

It is here that the life of St Antony of Egypt reveals its ongoing relevance to the life of African Pentecostalism - of which he might be called a precursor. Antony's life is a picture of vibrant spirituality, deeply rooted in the native soil of Egypt, yet coupled with thoughtful engagement with the theological issues of the day. It provides a compelling model for African Pentecostals to couple a vibrant spirituality with theological depth. This study explores aspects of Antony's spirituality and draws lessons from it for contemporary African Pentecostalism.

\section{METHODOLOGY}

The study proceeds first by discussing Antony's context: the early Egyptian Christianity that shaped his faith. It then examines Antony's life, including some assessment of the primary sources on Antony and information about his seven extant letters. From there it delves into an exploration of Antony's worldview, his understanding and use of scripture, prayer, and spiritual warfare. For this, the study draws primarily from Antony's letters with some reference to Athanasius' biography. It concludes with some final reflections on Antony's life and legacy for African Pentecostal Christians.

\section{The Context of Early Egyptian Christianity}

Any exploration of a historical figure like Antony must take account of his context - the sociocultural, political, economic, intellectual, and especially religious realities which influenced him. The perceived distance between Antony's world, and the world today, is reduced when the context that shaped his life and spirituality are more fully known. He can only be fully understood and interpreted in his context.

\section{Sociocultural, Political \& Economic Context}

Antony of Egypt was born in 251 in Lower Egypt. Like much of contemporary Africa, Antony's Egypt was a dynamic multicultural, multilingual, and multi-religious society. Egypt had always been a cultural meeting place, with Nubians from the Upper Nile intermingling, trading with, sometimes ruling and being ruled by indigenous Egyptians in the Lower Nile Valley. Approximately five hundred years earlier, Alexander the Great's conquest and inclusion of Egypt to his empire introduced the Greek language and a cosmopolitan Hellenistic culture that overlay existing Egyptian society. In the ensuing centuries of the Hellenistic period, Egypt became home to a large well-established Jewish community. ${ }^{8}$ These Diaspora Jews were culturally Hellenised, Greek-speaking, and many were fully engaged with the Greek intellectual tradition and contributed to the religious dynamism of Egypt. Roman conquest came shortly before the turn of the millennium and brought with it its own cultural, legal, social and economic influence. Egypt was, by Antony's time, an amalgamation of Semitic, Greek, Roman, Nubian, and native Egyptian cultural elements.

After the fall of Alexander's Greek Empire, the Ptolemaic dynasty that succeeded it in ruling Egypt and later the Romans who defeated and replaced them were both challenged by the need to rule a people whose 'culture, whose languages and social formation (mode of production) were incongruent with their own'. ${ }^{9}$ The Ptolemies largely followed the Pharaonic system of economic and political management, wherein all property

6 Rudolph Otto, The Idea of the Holy, translated by John Harvey (London: Oxford University Press, 1950), 64.

7 Simon Chan, Spiritual Theology: A Systematic Study of the Christian Life (Downers Grove, IL: InterVarsity Press, 1998), 15.

8 According to Philo, the number of Jewish inhabitants of Egypt was at least one million. While perhaps exaggerated and difficult to prove in any case, it shows that the number of Jews was not insignificant. Philo, In Flaccum VII in The Works of Philo translated by C.D. Yonge (Peabody, Massachusetts: Hendrickson Publishers, 1993), 728.

9 Henry A. Green, 'The Socio-Economic Background of Christianity in Egypt', in Birger Pearson and James Goehring (eds.), The Roods of Egyptian Christianity (Philadelphia: Fortress Press, 1986), 101. 
was owned and managed by the state. ${ }^{10}$ The Romans however introduced private property, 'extend[ed] to imperial favorites imperial grants (of land)', and introduced tax reforms. ${ }^{11}$ Henry Green argues that these reforms led to 'the polarization of the population into Romans/Greeks and Egyptians' and that it also 'lay at the root of social and psychic dislocation in the first century'. ${ }^{12}$ Arguably it was this dislocation that created an opening for the emergence of Christianity as a viable alternative to the now socially marginalised but educated non-Greek populations of Egypt. ${ }^{13}$ One may perceive parallels to this in the rapid growth of Christianity on the continent in the wake of $20^{\text {th }}$ century African independence movements and subsequent political and economic crises. For most Egyptian peasants however, little changed. 'The native Egyptian peasants continued to perform the same economic tasks they had performed under the Ptolemies and received the same social benefits. ${ }^{14}$ Life in rural Egypt continued largely as it had for centuries, mostly undisturbed by the transformation taking place in the urban centres of the Nile delta.

\section{Intellectual Context}

Alexandria, situated in Egypt's Nile delta, was one of the largest cities in the Roman Empire and was the intellectual centre of the Græco-Roman world. It was home to 'the most famous library in ancient times... the Museum of Alexandria' ${ }^{15}$ a situation that 'assured the preservation of the literary legacy of the Greeks' ${ }^{16}$ It was in Alexandria where, in the $3^{\text {rd }}$ century B.C., the first translation of the Hebrew Bible into Greek took place. ${ }^{17}$ The Septuagint (or $L X X$ ), as this translation came to be called, was the scripture used by Christ and his disciples and provided early Christians with 'an arsenal of terms and concepts for expressing the content and symbols of the Christian faith ${ }^{18}$ - contents and symbols which were native to Semitic culture but alien to the Hellenistic world. Alexandria was also the place where the tools of philology first began to be applied to Christian texts. ${ }^{19}$ The Alexandrian school 'exerted great influence on the whole of Antiquity (sic)' including scholars like Philo the Jew, Clement and Origen. ${ }^{20}$ These scholars adapted the Greek method of allegorical interpretation for use in scriptural hermeneutics; 'it was perfect for reconciling an ancient classical tradition... to a new situation and a new mentality. ${ }^{21}$ Stoic and Neoplatonist influences from Greece found their way into Egypt as well. ${ }^{22}$ These developments illustrate the intellectual fervour and dynamism characteristic of Egypt in Antony's time.

This intellectual fervour was not restricted to the urban areas alone. Although the small towns and villages of rural Egypt from which Antony hailed were certainly not cosmopolitan centres, there is evidence of 'close contacts between Alexandria, and even the world beyond, and the Egyptian countryside'. ${ }^{23}$ It can thus be surmised that although Antony was not himself an urbanite, he would have been in touch with the intellectual dynamism of larger Egyptian society, and probably familiar with Greek philosophical culture. Literacy in the Greek language was widespread. Though Coptic was spoken by the masses of the common folk, knowledge of spoken Greek was not uncommon. ${ }^{24}$ In this way, life in Antony's Egypt was much like life in contemporary Africa, where official languages vie with and are complemented by various mother-tongues. Like many Africans today who have been exposed to formal education, and thus are at least somewhat literate

${ }^{10}$ Green, 'The Socio-Economic Background of Christianity in Egypt', 102.

${ }^{11}$ Green, 'The Socio-Economic Background of Christianity in Egypt', 104, 107.

12 Green, 'The Socio-Economic Background of Christianity in Egypt', 109.

${ }^{13}$ Green, 'The Socio-Economic Background of Christianity in Egypt', 110.

${ }_{14}$ Green, 'The Socio-Economic Background of Christianity in Egypt', 108.

15 Julio Trebolle Barrera, The Jewish Bible and the Christian Bible: An Introduction to the History of the Bible (Leiden, The Netherlands: Brill Academic Publishers, 1998), 137.

16 Barrera, The Jewish Bible and the Christian Bible, 138.

17 John S. Mbiti, Bible and Theology in African Christianity (Nairobi: Oxford University Press, 1986), 22.

18 Barrera, The Jewish Bible and the Christian Bible, 301.

19 Barrera, The Jewish Bible and the Christian Bible, 116.

20 Barrera, The Jewish Bible and the Christian Bible, 137.

21 Barrera, The Jewish Bible and the Christian Bible, 528.

22 Barrera, The Jewish Bible and the Christian Bible, 139.

23 Samuel Rubenson, The Letters of St. Antony: Monasticism and the Making of a Saint (Minneapolis: Fortress Press, 1995$), 96$.

${ }^{24}$ Rubenson, The Letters of St. Antony, 98. 
in French or English, it is likely that Antony had some degree of literacy in Greek, the international language of the day.

\section{RELIGIOUS CONTEXT}

Christianity was well established in Egypt by the $3^{\text {rd }}$ and early $4^{\text {th }}$ century, though the origins are somewhat obscure. Acts 18:24-25 speaks of a Jew from Alexandria named Apollos who had been instructed in the Way of the Lord and spoke eloquently about Jesus. He came to Ephesus where he received further instruction from Prisca and Aquila about the Christian faith. This is the first direct reference to Egyptian Christianity and whatever else this passage means, it certainly points to an early date for the establishment of a Christian presence there. The large Jewish presence in Egypt probably influenced the practice of Egyptian Christianity as indeed it is quite likely that Christianity first spread amongst the Diaspora Jews resident there. Albertus Klijn writing about Jewish Christianity in Egypt cites the writings of Clement and Origen to argue that at the beginning of the $3^{\text {rd }}$ century there were substantial numbers of Jewish-Christians in Egypt. ${ }^{25}$ There is also good reason to suspect that the Epistle to the Hebrews, with its 'bold allegorical doctrine about the role of Jesus as the heavenly high priest' ${ }^{26}$ was written in Egypt.

Outside the urban areas of Lower Egypt, there is evidence of significant Christian presence in Upper Egypt in the $3^{\text {rd }}$ century. ${ }^{27}$ The church itself at that time was apparently growing in wealth and influence: 'the documentary material... shows that the Church... rapidly accumulated considerable wealth' ${ }^{28}$ Egypt of Antony's time also saw the rise of Christian schools, first in Greek areas but later extended to Coptic speaking areas as well. 'In these church schools, classical tradition and the Greek language were taught together with the Scriptures'. ${ }^{29}$ This is an important factor in understanding Antony's own life and experience as he may have been educated in such a setting himself and thus exposed to the broader Greek philosophical tradition. The increasing wealth of the church and the rise in education mirror similar trends in contemporary African Pentecostalism, where 'issues of upward mobility and success, wealth creation, the importance of higher education, [and] investment' are increasingly seen as markers of a 'progressive family life' ${ }^{30}$ It has been suggested that Christianity in Egypt was heavily influenced by Gnosticism, but Rubenson's survey of early textual evidence shows that this was not the case, but that 'third century Egyptian Christianity [was] strongly Biblical, and much less Gnostic than has been suggested.' ${ }^{31}$ Taken together these factors present a picture of a broad and deeply established Christian community containing both Hellenistic and native Egyptian elements.

\section{Antony: Sources and Documents}

Most of what is known of Antony's life comes from the Life of Antony written by his admirer Athanasius, the Bishop of Alexandria. There are, however, a number of references to Antony in other sources as well. Rubenson notes that Antony is also referred to 'in a letter by Serapion of Thmuis, in the Pachomian literature, in the writings of Jerome and Rufinus, in the Historia Monachorum, in Palladius, and in the histories of Socrates, Sozomenus and Theodoret'. ${ }^{32}$ While these sources are not cited as sources for this essay, they demonstrate the extent of Antony's influence as well as provide additional insight into the substance of his ministry, even while providing little additional information about Antony himself.

\section{The Life of Antony}

The Life of Antony was written by Athanasius, probably between 356 and 362 ostensibly as a response to those who asked him for 'an account of the blessed Antony's way of life...how he began the discipline, who and

\footnotetext{
${ }^{25}$ Albertus F.J. Klijn, 'Jewish Christianity in Egypt', in Birger Pearson and James Goehring (eds.), The Roots of Egyptian Christianity (Philadelphia: Fortress Press, 1986), 164.

${ }_{26}$ Robert M. Grant, 'Theological Education at Alexandria', in Birger Pearson and James Goehring (eds.), The Roots of Egyptian Christianity (Philadelphia: Fortress Press, 1986), 180.

27 Rubenson, The Letters of St. Antony, 106.

28 Rubenson, The Letters of St. Antony, 107.

29 Rubenson, The Letters of St. Antony, 109.

30 Asamoah-Gyadu, Sighs \& Signs of the Spirit, 16.

31 Rubenson, The Letters of St. Antony, 111.

${ }^{32}$ Rubenson, The Letters of St. Antony, 163-164.
} 
what manner of man he was previous to this, how he closed his life, and whether the things told of him are true'. ${ }^{33}$ Beyond this pious motivation, it is likely that Athanasius had other motives as well for writing The Life of Antony. David Brakke argues that The Life of Antony was written to 'promote Anthanasius' political goal of a church united under the Alexandrian episcopate'. ${ }^{34}$ As Bishop of Alexandria during a time of transition and in the face of various controversies facing the church including the challenge of Arianism, it could hardly be otherwise. Despite these apparently mixed motivations, this work remains the primary source document for information about Antony's life and ministry in the desert.

From Athanasius, it is learnt that Antony was an Egyptian by descent, which is to say that he was a native of Egypt and not of Greek, Roman or Jewish extraction. It is also revealed that he was brought up by Christian parents who were 'of good family and possessed considerable wealth', but that he rejected formal education as he grew older. ${ }^{35}$ Around the age of 18 or 20, he was orphaned and left with the care of his younger sister. About that same time, Antony received the calling to the ascetic life, a calling to which he responded wholeheartedly. He began first by attaching himself to various hermits who lived in nearby villages, 'subject[ing] himself in sincerity to the good men whom he visited, and learn[ing] thoroughly where each surpassed him in zeal and discipline'. ${ }^{36}$ This served as a kind of spiritual apprenticeship, not unlike that which traditionally has occurred in African settings. Antony then had a series of encounters with evil spirits, and various other spiritual trials. After some twenty years of 'training himself in solitude', a community of disciples began to gather themselves around Antony in order to 'imitate his discipline'. ${ }^{37}$

A substantial portion of The Life of Antony consists of recitations of Antony's teachings, his miraculous deeds, his spiritual encounters, his clairvoyance, and descriptions of his laudable character. He is described as humbly submissive to the structures of the Church - 'willing that all the clergy should be honoured above himself' ${ }^{38}$ - and ardently opposed to the Meletians, Manichaeans, ${ }^{39}$ and Arians. ${ }^{40}$ These descriptions undoubtedly served Athanasius' overarching purpose of 'preclud[ing] any fellowship between Antony and Athanasius' opponents'. ${ }^{41}$

\section{The Letters of Antony}

The other primary source of information about Antony is seven letters attributed to him. These letters reflect Antony's own thoughts as captured in his correspondence and are therefore key to understanding his spirituality. Versions of all or part of each of the letters exist in Coptic, Arabic, Greek, Syriac as well as Georgian. ${ }^{42}$ Though Greek was the lingua franca of the day and widely spoken in Egypt, Rubenson has amassed evidence which suggests that Antony's letters were originally written in the Coptic language and later translated. They are therefore to be 'regarded as one of the first examples of original Coptic literature that have been preserved' which makes Antony 'not only the father of the monastic tradition, but quite possibly 'the first real Coptic author". ${ }^{43}$ The picture of Antony that emerges from his letters differs in significant ways from that found in The Life of Antony and other sources chiefly due to the familiarity with Greek philosophy demonstrated in the letters, which appears at odds with Athanasius's portrayal of Antony as unlettered. Therefore some 'scholars have either rejected the authenticity of the letters or tacitly avoided the problem they present for the established tradition. ${ }^{44}$ Rubenson however demonstrates that there is substantial evidence for Antonian authorship. ${ }^{45}$ Rubenson's argument is compelling, and the author proceeds on the assumption that the letters

${ }_{33}$ Athanasius, Life of Antony in The Nicene and Post-Nicene Fathers Series 2: Athanasius: Select Works and Letters, Philip

Schaff (ed.) Vol. 4 (Edinburgh: T\&T Clark, 1892), Kindle Edition 530430.

${ }^{34}$ David Brakke, Athanasius and the Politics of Asceticism (New York: Oxford University Press, 1995), 203.

${ }^{35}$ Athanasius, Life of Antony 1.

36 Athanasius, Life of Antony 4.

${ }^{37}$ Athanasius, Life of Antony 14.

${ }_{38}$ Athanasius, Life of Antony 67.

${ }^{39}$ Athanasius, Life of Antony 68.

40 Athanasius, Life of Antony 69.

${ }^{41}$ Brakke, Athanasius, 247.

${ }^{42}$ Rubenson gives a full analysis of the various versions in chapter 1 of his book. Rubenson, The Letters of St. Antony, 15 -34.

${ }^{43}$ Rubenson, The Letters of St. Antony, 185.

${ }^{44}$ Rubenson, The Letters of St. Antony, 11.

${ }^{45}$ Rubenson, The Letters of St. Antony, 12. 
are genuine. However, neither defending nor subverting traditions about Antony and early monasticism is his concern. He is rather concerned to unpack what the letters reveal about Antony's spirituality.

\section{The Spirituality of Antony's Worldview}

This section begins with an examination of Antony's worldview because it is the framework within which his spirituality can be properly understood. The term worldview here refers to what Ninian Smart calls 'what folks feel, the ideas they have, [and] the structure of belief of their societies. ${ }^{36}$ There are three aspects of the worldview that shall be considered here: cosmogony, identity, and spirit beings.

\section{Cosmogony}

One of the first things that one notices about Antony's worldview is his cosmogony. Cosmogony pertains to the theory of the origins or the generation of the universe. ${ }^{47}$ Antony held that all beings including humans, by whatever name they are called, whether good or evil, derive from one source which is God. In Letter Five he says:

Now, therefore, understand that, whether it be the holy heavens or angels or archangels or thrones or dominions or cherubim or seraphim or sun or moon or stars, or patriarchs or prophets or apostles, or devil or satan (sic) or evil spirits or the powers of the air, or (to say no more) whether it be man or woman, in the beginning of their formation they all derive from one, except the perfect and blessed Trinity: Father, Son, and Holy Spirit. ${ }^{48}$

Again, in Letter Six (this time in specific reference to demons) one reads: 'They [demons] are, moreover, all from one (source) in their spiritual essence. ${ }^{49}$ Antony's perspective is not unusual; Christians generally believe that God is the creator or source of all. Yet what emerges from these excerpts is the strong sense Antony holds of the essentially spiritual nature of all these entities, including what some would consider strictly natural phenomena like the sun, moon and stars, and their fundamental reliance upon God for their origination and continued being. This derives from Antony combining the Platonic concept of the unity of God with the biblical testimony about creation. ${ }^{50}$ The joining of these two concepts means that in Antonian cosmogony, 'all rational nature' - that is all those with the capacity of reason - 'was originally made in the image of God's mind, which is Christ. ${ }^{51}$ This notion is expressed explicitly in Letter Seven where Antony describes Christ as, 'the life of every rational being created by him in his own image, for he is the true mind of the Father and he is the immutable image of the Father. ${ }^{52}$ This again reinforces the idea that in Antony's understanding, Christ is the origin and sustainer of all; reality is therefore ultimately spiritual, personal and God-derived. This spiritual reality precedes and underlies the physical expression of it and extends not only to human beings made "in the image of God" but to every kind of rational, spiritual being, including the demonic.

\section{Identity}

Antony's understanding of identity is a direct consequence of his cosmogony. He does not hold to what I term "ontological essentialism" but holds that beings derive their identities, and thus their names, not from what they are in their essential nature, but from what they do. Therefore, since God is the source of all things, Antony considers that even 'demons have not been created like what we mean when we call them by that name; for God made nothing evil'. ${ }^{53}$ It is rather, 'because of the evil conduct of some, it was necessary that God should set names upon them after their works. ${ }^{54}$ From this perspective, identity derives from one's action and is not a consequence of being; it is a matter of participation and not creation, for both humans

\footnotetext{
46 Ninian Smart, Worldviews: Crosscultural Explorations of Human Beliefs (New York: Charles Scribner's Sons, 1983$), 2$.

47 Oxford Universal Dictionary (London: Oxford University Press, 1933), 401.

48 Antony, Letter Five in Rubenson, The Letters of St. Antony, 215.

49 Antony, Letter Six, 220.

50 Rubenson, The Letters of St. Antony, 64.

51 Rubenson, The Letters of St. Antony, 65.

52 Antony, Letter Seven, 225.

53 Athanasius, Life of Antony 22.

54 Antony, Letter Five, 215.
} 
and for other spiritual beings. 'Man's incurable wound and his need for redemption are attributed to the long history of his disobedience to the natural law implanted in him at his creation... rather than to a cosmic fall. ${ }^{55}$ Consequently, the degree of evil and the nature or characteristics of various spiritual beings varies in relation to their actions. ${ }^{56}$ This has implications for Antony's spirituality and especially for his view of spiritual warfare as shall become evident.

Tied to Antony's view of identity is his understanding of the importance of names. The significance Antony gives to names and their function is seen repeatedly in how he addresses the recipients of his letters. In Letter Three the phrase 'your names in the flesh' appears and is contrasted against the 'true name' which, if known, will allow perception of 'the name of Truth'. ${ }^{57}$ It is this true name which will endure, as the other will, in Antony's estimation, pass away. This idea is repeated in Letter Five, ${ }^{58}$ in Letter Six, ${ }^{59}$ and Letter Seven. ${ }^{60}$ Antony links the knowledge of this 'true name' to the account of Jacob's wrestling with God: 'As long as he was struggling with the angel through the night Jacob was called Jacob, but when it dawned he was called Israel, which means "a mind that sees God". ${ }^{61}$ It was only when God revealed to Jacob his true identity and name as Israel that Jacob was enabled to truly know God. Consequently, Antony refers to his readers as 'Israelite children' ${ }^{62}$ which he sees as their spiritual, and thus true, identity; they are those who have received true knowledge of themselves and therefore of God. Again one sees the influence of Platonic philosophy on Antony's thought, particularly in its emphasis on the dualism between the spiritual and corporeal with the real self-being identified with the spiritual essence. ${ }^{63}$ The Platonic tradition of self-knowledge as a means of salvation is also in view here. ${ }^{64}$ Antony combines this Greek philosophical concept with the gospel to develop a framework of identity wherein one's name/identity is deeply bound together with experiential knowledge of God. The use of the true name, that is the spiritual name, is seen to have cosmic significance.

\section{Spiritual Beings}

Antony's world is one in which an abundance of spiritual beings reside. Earlier sections have already mentioned some of these: angels, devils, sun, moon, stars, men and women, etc. ${ }^{65}$ and discussed briefly Antony's view of their origin and essence. Aside from human beings, Antony seems to consider these spiritual beings as either adversaries to Christians, motivated by jealousy, ${ }^{66}$ or as aids to them, instruments of God's mercy. Sun, moon, stars and other 'hidden powers', he says, are given to 'serve us [Christians] though we do not see them with our bodily eyes ${ }^{9}{ }^{67}$ Though originating in God, these beings are conceived of as having some degree of independent will as well as distinct personal characteristics and pursuits. ${ }^{68}$ They are thus personal beings and not mere forces, emanations, or an undistinguished mass of spirits.

The inclusion of those ones may broadly term saints - patriarchs, prophets, and apostles ${ }^{69}$ - in Antony's world have been mentioned. What is notable from the perspective of African Christianity is the important role they play in the lives of believers. He says of these saints: 'Did not the patriarchs suffer for us, did not the priests teach us, did not the judges and the kings fight for us, did not the prophets die for us, or were not the apostles persecuted for us...? ${ }^{70}$ Though this recitation is of their past deeds, one senses the degree to which Antony perceives their ongoing relevance. He views the dead and the living as bound together by a common

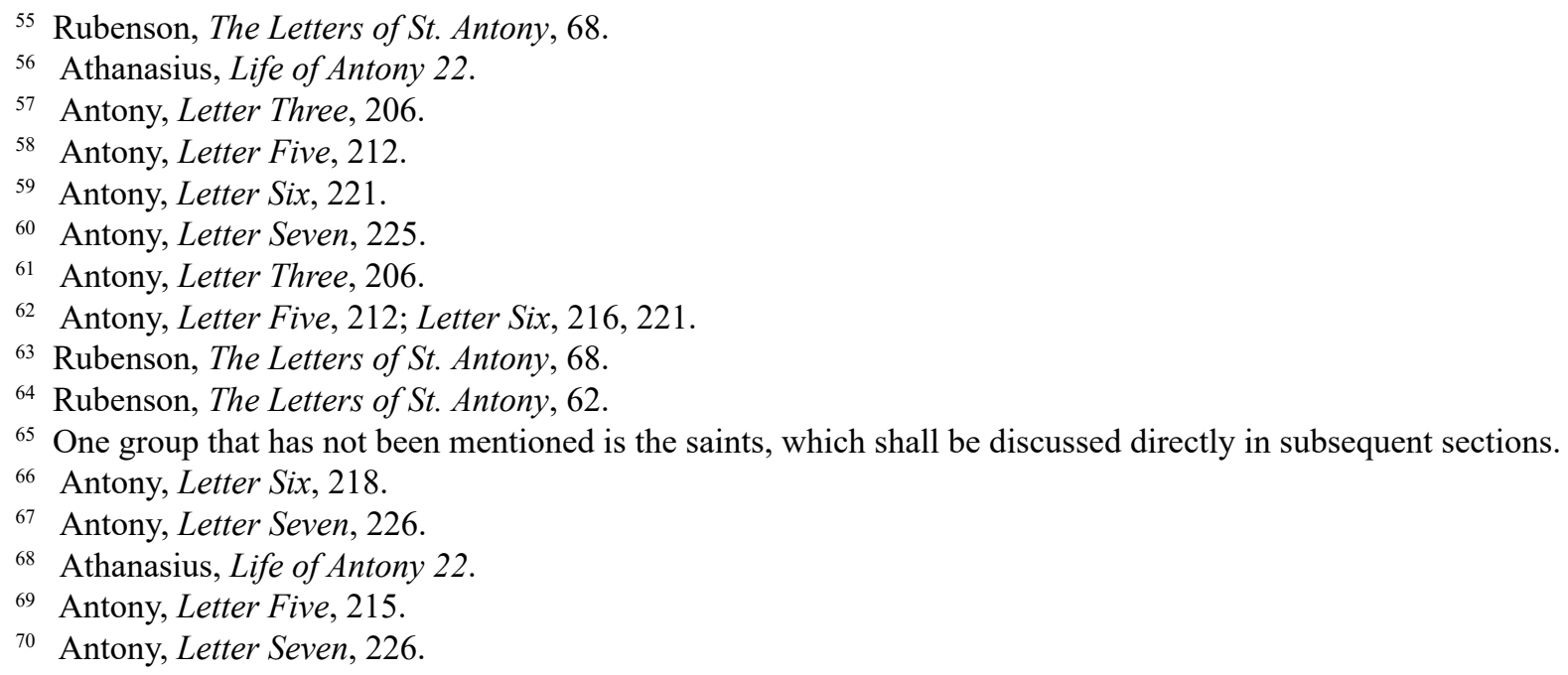


struggle for wholeness. The 'negligence, humiliation and outward confusion' experienced by living Christians residing in, what Antony calls, 'a house of robbers...bound by the bonds of death', is seen by Antony as the cause of 'labour to the angels and all the holy in Christ, since for our sake they have not yet found peace'. ${ }^{71}$ Again he says, 'I see the great distress that comes upon us all and contemplate the struggle of the saints and their tears, which they shed at all times before God for our sake' ${ }^{72}$ Here Antony exhibits a keen awareness of the interdependence of the living and dead found in Hebrews 11.40 where the author says that the saints will not be made perfect apart from us. The dead are neither absent nor disconnected from the life and faith of the living, but the experience and activity of one group has consequences for the other.

\section{Scripture}

Scripture plays a key role in Antony's spirituality in every phase and aspect of his life as a source of both insight and instruction. Antony's engagement with scripture displays some resonances with African Pentecostal usage and is therefore noteworthy.

The first insight into Antony's engagement with scripture is evident prior to his initial calling to the ascetic life. According to Athanasius, as a child Antony was 'attentive to what was read, keeping in his heart what was profitable in what he heard'73 as he attended Christian worship with his parents. Though the description of Antony as a precocious student of scripture is probably exaggerated, certain key elements emerge from it. The first is that Antony's engagement with scripture seems to have been primarily in oral form. This mirrors contemporary African Pentecostalism where great emphasis is laid on the spoken word as 'a vital component of Pentecostal spirituality' that carries within it 'the power of transformation' ${ }^{74}$ The second, connected with the first is that the language in which Antony heard the scripture was presumably Coptic, his mother-tongue. This is not an unimportant factor for it suggests that Antony's experience of the scripture was within the framework of existing systems of Coptic Egyptian thought which had been converted to Christ. ${ }^{75}$ The final one is that Antony heard scripture within an established church, which tells that from childhood he was being shaped by a Christian community fully at home with the Coptic scriptures. Antony's Coptic Egyptian linguistic background thus features as an important element of his spirituality; he was a Coptic Christian, listening to Coptic scriptures, following a Christ fully at home in the Coptic culture.

\section{Scripture and the Call to the Ascetic Life}

Scripture appears as a key element in Antony's calling to the ascetic life. From Athanasius it is read that shortly following the death of his parents, Antony entered the church reflecting upon certain scriptural accounts of the apostles:

It happened that Gospel was being read, and he heard the Lord saying to the rich man, If thou wouldest be perfect, go and sell that thou hast and give it to the poor; and come follow Me and thou shalt have treasure in heaven. ${ }^{76}$

One sees in this the importance of the spoken text of scripture in Antony's spiritual formation. It is not through the study of scripture that he is called but through the hearing of it. Antony understood this scripture as a living voice, the direct means through which God was speaking to him. A similar perspective may be observed among African Pentecostals, who take scripture seriously as a roadmap for the Christian life. Yet there is a key difference. While contemporary African Pentecostals often employ a hermeneutic that 'reflect[s] a belief in a gospel of success, upward mobility and achievement', ${ }^{77}$ Antony's reception of the gospel led him to give away his possessions to the villagers and the poor, retaining only a portion with which to cater for his

71 Antony, Letter Six, 223.

72 Antony, Letter Six, 217.

73 Athanasius, Life of Antony 1.

74 Asamoah-Gyadu, Sighs and Signs, 77.

75 Andrew Walls refers to this process of conversion inherent in translation: "conversion implies the use of existing structures, the "turning" of those structures to new directions, the application of new material and standards to a system of thought and conduct already in place and functioning'. Andrew F. Walls, 'The Translation Principle in Christian History', in The Missionary Movement in Christian History: Studies in the Transmission of Faith (Maryknoll, NY: Orbis, 1996), (28).

76 Athanasius, Life of Antony 2,.

77 Asamoah-Gyadu, Sighs and Signs, 48. 
sister for whom he was now responsible. This initial renunciation was only partial, for later, Antony again heard God speak through scripture, and consequently sold the little he had remaining, and 'henceforth devoted himself outside his house to discipline, taking heed to himself and training himself with patience' ${ }^{78}$ Antony's engagement with scripture challenges hermeneutics that read the scripture as a source from which 'lessons on how to prosper [may be] drawn'. ${ }^{79}$ Scripture was, rather, the basis upon which Antony was launched into the ascetic life.

\section{Scripture and Spiritual Discipline}

It is not only in the initial calling to asceticism however that scripture informed Antony's spirituality. The Life of Antony contains several references to his engagement with scripture throughout his life. For example, Athanasius remarks that at the beginning of his journey into asceticism, Antony worked to provide himself with food and that he devoted himself to constant prayer, actions based on the scriptural instructions found in 2 Thessalonians 3.10 and 1 Thessalonians 5.17. ${ }^{80}$ Later, as his reputation grew, many came to ask his advice and the beginnings of a monastic community started to spring up around him. In response to this development, Antony spoke to his disciples of the importance and sufficiency of scripture in Christian life by saying 'The Scriptures are enough for instruction, but it is a good thing to encourage one another in the faith and to stir up with words. ${ }^{91}$ Indeed even the physical discipline Antony imposed on himself was an outworking of scriptural admonition in Matthew 6.31-33. ${ }^{82}$ These examples demonstrate the extent to which scripture formed the basis upon which Antony's spirituality was grounded. The central place Antony gives to scripture becomes even more apparent when his letters are examined.

Each of the seven letters of Antony contains multiple scriptural references smoothly integrated into the text of the letter. One senses immediately the extent to which Antony is at home with scripture, using it freely both to bolster substantive points of instruction for his readers and to flavour the more mundane parts of his text. For example, in the closing of Letter Three he says 'there is much to be told to you, but if one gives occasion to a wise man, he will be yet wiser. I greet you all from the least to the greatest. ${ }^{83}$ This closing, though simple, contains references to two different scripture passages: Proverbs 9.9 and Acts 8.10. ${ }^{84}$ His briefest letter, Letter Four, contains no fewer than six references or allusions to scripture ${ }^{85}$ from both the Old and New Testament: Ephesians 3.1 (conflated with Philemon 1.1), John 15.15, Romans 8.15-17, Sapientia 1.4-5, ${ }^{86} 1$ Corinthians 10.15 , and 1 Samuel 2.25. Antony vividly uses scripture, drawing his readers into dynamic participation with the text:

Prepare yourselves to come to your Creator, rending your hearts and not your garments, and bear this in mind: What shall we render to the Lord for all the benefits that he has done to us; in his great benevolence and his incomprehensible love, he remembered us, even in this our dwelling and humiliation (sic). ${ }^{87}$

In this passage Antony directly exhorts his readers using the words of scripture. Antony uses Joel 2.13 and Psalm 115.3 as direct appeals from God himself, to which the hearer must now respond. It is their hearts which must be rent in repentance; it is their responsibility to render to God what is his due in response to his benevolence. Antony's extensive and dynamic use of scripture shows both familiarities with the text and

\footnotetext{
78 Athanasius, Life of Antony 3.

79 Asamoah-Gyadu, Sighs and Signs, 48.

${ }^{80}$ Athanasius, Life of Antony 3.

${ }^{81}$ Athanasius, Life of Antony 16.

${ }^{82}$ Athanasius, Life of Antony 45.

83 Antony, Letter Three, 209.

${ }^{84}$ He uses a similar closing for Letter Two, p. 205, Letter Six, p. 224, and Letter Seven, p. 231. The Acts 8.10 passage is not readily apparent as a direct reference to scripture and seems a bit incongruous given the context. However, Rubenson's translation indicates through italicization that it is a scriptural reference located within the body of Antony's letter.

85 Antony, Letter Four, 206-207.

${ }^{86}$ This book, which does not appear in contemporary Bibles, is found in the Septuagint.

87 Antony, Letter Seven, 226.
} 
faith in it as the word of God, and he assumes both on the part of his readers. His use of scripture further demonstrates that it is not a flat text to Antony. He does not approach the text from the standpoint of a passive observer but as an active participant. Scripture is to him a living dynamic reality in which Christians actively participate through hearing and responding in obedient faith.

\section{Prayer \& Spiritual Warfare}

The article now considers two other important aspects of Antonian spirituality: prayer and spiritual warfare. These are considered together because, in Antony's life, they are interconnected, mutually reinforcing facets of his spirituality.

In his letters, prayer is often discussed in the context of the history of salvation. He describes salvation history prior to Christ as the uncompleted foundation first laid by Moses and later built upon by the prophets. Ultimately however these prophets realise 'that the wound was incurable and that none of the creatures was able to heal it ${ }^{\prime}{ }^{88}$ and they, therefore, cry out to God in prayer for him to send healing to his people. Prayer in this case is understood primarily as intercession for God's salvific intervention as a healer to his people for the wound of sin. It is a plea for the coming of Christ. Beyond this, Antony in his letters describes his own prayers for his readers and encourages them in prayer as well. In Letter Six, for example, Antony exhorts his readers to "pray and beseech the benevolence of the Father until he comes to our help and we thus may find rest at the coming of Jesus and strength so that we are able to follow the saints' ${ }^{89}$ and later, 'do not fail to beseech the goodness of the Father that perchance a helper will come to you so that you may teach yourselves to know what is truly right' ${ }^{90}$ In each case, intercession is seen as a plea for support in the spiritual battle in which believers are engaged.

A fuller picture emerges from the Life of Antony. Concerned as Athanasius is to demonstrate the piety and imitability of Antony's life, his interactions with hostile spiritual beings loom large. Prayer plays a key role in these interactions. Athanasius describes the devil as being 'overthrown by [Antony's] great faith and falling through his constant prayers'. ${ }^{91}$ Following one particularly harrowing encounter, Antony is beaten badly and is therefore unable to stand for prayer. Nevertheless, he continues to pray whilst lying down and strengthened by the prayer, he boldly confronts his enemy, 'Here am I, Antony; I flee not from your stripes, for even if you inflict more nothing shall separate me from the love of Christ. ${ }^{92}$ Antony also advises that the demons can be easily foiled since 'by prayer, fasting, and faith in the Lord their attack immediately fails. ${ }^{\prime 93}$ In both of these cases prayer functions as a means of fortification against spiritual enemies, in much the same way as it does amongst African Pentecostals. Connected with this is the Antonian idea that the nature or characteristics of various spiritual beings vary in relation to their actions. Prayer is thus needed in order to 'recognise their characteristics: which of them are less and which more evil of what nature is the special pursuit of each, and how each of them is overthrown and cast out. ${ }^{94}$ In Pentecostal terms, this is discerning of spirits. On another occasion, Athanasius describes how prayer enabled Antony to do the miraculous: 'when he was obliged to cross the Arsenoitic Canal... the canal was full of crocodiles. And by simply praying, he entered it, and all they with him, and passed over in safety. ${ }^{95}$ In these examples, prayer functions primarily as a means by which to access spiritual power rather than as a means for communion with God.

\section{Sacred Spaces}

A sacred place does not necessarily refer to an arena of holy encounter, but rather to the sacramental sense in which the physical environment itself portends a kind of spiritual encounter. This leads to the final area of consideration of Antony's spirituality - one that does not immediately present itself, yet without which the totality of Antony's life makes little sense - the desert. The journey into solitary places has been interpreted as

${ }_{88}$ Antony, Letter Two, 204; Letter Three, 207, Letter Five, 213 and Letter Six, 216.

${ }^{89}$ Antony, Letter Six, 217.

${ }^{90}$ Antony, Letter Six, 219.

${ }_{91}$ Athanasius, Life of Antony 5.

92 Athanasius, Life of Antony 9.

93 Athanasius, Life of Antony 23.

94 Athanasius, Life of Antony 22.

95 Athanasius, Life of Antony 15. 
a means by which one could escape the corruption of city life; "the easiest way of obtaining this renunciation [of the world] was expatriation to the desert place, anywhere, at any rate, away from the town. ${ }^{96}$ However, this interpretation belongs more to the later European monastic movement which was in many ways a protest against an irreligious Christendom than it does to Antonian Egypt. Donald Bloesch's perspective comes closer to what is found in Antony when he describes the call to the desert as, 'a call to extricate ourselves from worldly entanglements', and as, 'go[ing] to the front lines in the war between light and darkness. ${ }^{\text {'97 }}$ One may see in this resonances of the holiness ethic of African Pentecostals, for whom 'personal transformation from life in the world to a new life in Christ, involving a renewal of the whole person for a life of holiness ${ }^{\prime 98}$ is the sure sign of authentic Christian commitment. Yet Antonian holiness was far from being simply an escape or retreat from the cares of life, or a means by which to separate oneself from "the world". Antony's life of desert monasticism was one of aggressive intrusion into the very territories where demonic influences were presumed to prevail. Indeed it was only after Antony had been fortified through his early practice of discipline and had triumphed in his first struggles against evil that he 'departed to the tombs, which happened to be at a distance from the village'. ${ }^{99}$ Here the spiritual struggle intensified for the enemy feared 'that in a short time, Antony would fill the desert with the discipline' ${ }^{100}$ The implication is that the desert was a place where demons had the freedom to operate and that Antony's disciplined life of holiness was, therefore, a threat to them. In a sense, Antony's desert discipline recalls Jesus' own sojourn in the wilderness where he was driven by the Spirit after his baptism and where he was tempted by the devil and overcame. Throughout the Bible, the wilderness is most often portrayed as a place of trial, as in the sojourn of Israel in the wilderness whilst en route to Canaan. It is within this framework that Antony's spirituality should be understood, as a spirituality of engagement, not one of retreat.

\section{CONCLUSION}

Antony of Egypt presents a picture of a spiritually intense life, one lived fully in awareness of the immediacy and potency of spiritual power. His worldview, which included many supernatural forces arrayed against the success of Christian commitment, drove him to intense reliance upon prayer for fortification against these enemies. He saw himself as part of a community that transcended the boundaries of life and death, stretching backward in time to include the departed dead who participated with him in his struggle for holiness. Antony's understanding of identity formation - wherein a being becomes as a consequence of its action - led him to extremes of discipline of the body, the mortification of his bodily passions, so that his true spiritual identity could emerge. Furthermore, his belief in the efficacy of scripture as a living text rather than simply as history, philosophy, or a set of ethical instructions, led him to rely upon it as a means of both personal refreshments and as a tool against supernatural foes. He engaged with scripture in a dynamic way - responding in obedience to the immediacy of its claims upon him, calling upon it as a resource in a spiritual battle, and relying on it as a sure foundation for counsel to others.

Antony's discipline has been cited as an inspiration for monasticism, yet African Pentecostals would be well advised to drink deeply from the well of his spirituality. For those in the contemporary African scene, a few key lessons emerge. Firstly, Antony's spirituality is grounded in a deep knowledge of the scripture in his native tongue. African Pentecostals must likewise emphasize deep engagement with scripture as a living text through which God speaks to his people in their various mother tongues. Secondly, Antony's spirituality also is native to himself. Though conversant with Greek philosophical concerns and comfortable in the use of them, he evinces no need to limit himself to the Greek language or bind himself solely to Greek categories of thought. Antony is fully at home with his Coptic self, writing and speaking in the Coptic language. In the same way, while African Pentecostals need not be averse to rigorous engagement with the intellectual concerns of the present day, they also need not bind themselves to engage only on terms dictated by the

\footnotetext{
96 Herbert Workman, The Evolution of the Monastic Ideal (Boston: Beacon Press, 1962), 31.

97 Donald Bloesch, Spirituality Old \& New: Recovering Authentic Spiritual Life (Downers Grove, IL: InterVarsity Press, 2007), 57.

98 Asamoah-Gyadu, Sighs and Signs, 139.

99 Athanasius, Life of Antony 8.

100 Athanasius, Life of Antony 8.
} 
Western academy, or through imitation of Western methods, but must become comfortable in a genuinely dynamic dialogue that takes African culture seriously as a departure point for participation. Despite the divorce of theology from spirituality in the Western academy, intellectual excellence is not antithetical to a vibrant spiritual life or the belief in the supernatural. Indeed, the understanding of the supernatural ought to fully inform man's engagement with concerns of the contemporary academy as it did for Antony. Finally, Antony's spirituality is founded on prayer and in awareness of dependence upon God but was also undergirded by a vision of a sacramental world of divine presence. In a word, his spirituality was deeply primal, yet it was grounded in a profound theological vision. Contemporary African Pentecostals may also be commended for their dependency upon God for every aspect of life and remain in touch with the deeply spiritual intuition of African society. It is this primal spiritual sense that provides the seedbed for a vibrant spiritual theology, without which spirituality is reduced to a transactional religious pragmatism. As spirituality is that discipline that sustains, nurtures, and grows the transformative process of Christian faith, it becomes evident that heeding the lessons of Antonian spirituality should yield great fruits of a deeply spiritual theology that enriches and edifies Christ's church in Africa and beyond her shores as well.

\section{ABOUT AUTHOR}

Joshua D. Settles is a Research Fellow, Akrofi-Christaller Institute of Theology, Mission, and Culture, Akropong-Akuapem, Ghana.

\section{BIBLIOGRAPHY}

Antony, Letters One - Seven in Samuel Rubenson, The Letters of St. Antony, Minneapolis: Fortress Press, 1995.

Asamoah-Gyadu, J. Kwabena, Sighs and Signs of the Spirit: Ghanaian Perspectives on Penteccostalism and Renewal in Africa Akropong Akuapem: Regnum Africa, 2015.

Athanasius, Life of Antony in Philip Schaff(ed.), The Nicene and Post-Nicene Fathers Series 2: Athanasius: Select Works and Letters, Edinburgh: T\&T Clark, 1892. Kindle.

Augustine, Homilies on the Gospel of John; Homilies on the first Epistle of John; Soliliqies: Tractate 29. Vol. 7, in Philip Schaff (ed.), Nicene and Post-Nicene Fathers of the Christian Church, Edinburgh: T\&T Clark, 1995.

Barrera, Julio Trebolle, The Jewish Bible and the Christian Bible: An Introduction to the History of the Bible Leiden, The Netherlands: Brill Academic Publishers, 1998.

Bloesch, Donald, Spirituality Old \& New: Recovering Authentic Spiritual Life, Downers Grove, IL: InterVarsity Press, 2007.

Brakke, David, Athanasius and the Politics of Asceticism, New York: Oxford University Press, 1995.

Chan, Simon, Spiritual Theology: A Systematic Study of the Christian Life, Downers Grove, IL: InterVarsity Press, 1998.

Dickson, Kwesi, Theology in Africa, London: Darton, Longman, \& Todd, 1984.

Grant, Robert M., 'Theological Education at Alexandria', in Birgir Pearson, \& James Goehring (eds.), The Roots of Egyptian Christianity, Philadelphia: Fortress Press, 1986.

Green, Henry A., 'The Socio-Economic Background of Christianity in Egypt', in Birgir Pearson, \& James Goehring (eds.), The Roots of Egyptian Christianity, Philadelphia: Fortress Press, 1986.

Klijn, AlbertusF.J., 'Jewish Christianity in Egypt', in Birgir Pearson, \& James Goehring (eds.), The Roots of Egyptian Christianity, Philadelphia: Fortress Press, 1986.

Mbiti, John S., Bible and Theology in African Christianity, Nairobi: Oxford University Press, 1986.

Otto, Rudolph, The Idea of the Holy, translated by John Harvey, London: Oxford University Press, 1950.

Oxford Universal Dictionary, London: Oxford University Press, 1933.

Philo, In Flaccum VII, in Philo, The Works of Philo, translated by C.D. Yonge, Peabody, Massachusetts: Hendrickson Publishers, 1993. 
Rubenson, Samuel, The Letters of St. Antony: Monasticism and the Making of a Saint. Minneapolis: Fortress Press, 1995.

Smart, Ninian, Worldviews: Crosscultural Explorations of Human Beliefs, New York: Charles Scribner's Sons, 1983.

Walls, Andrew F., 'The Translation Principle in Christian History', in Andrew F. Walls, The Missionary Movement in Christian History: Studies in the Transmission of Faith, Maryknoll, NY: Orbis, 1996.

Workman, Herbert, The Evolution of the Monastic Ideal, Boston: Beacon Press, 1962. 